\title{
Bad Prognosis in Critical Ill Patients with COVID-19 during Short-Term ICU Stay regarding Vitamin D Levels
}

\author{
Lourdes Herrera-Quintana ${ }^{1}\left(\mathbb{D}\right.$, Yenifer Gamarra-Morales ${ }^{1}\left(\mathbb{D}\right.$, Héctor Vázquez-Lorente $^{1}(\mathbb{D}$, \\ Jorge Molina-López ${ }^{2, * \mathbb{D}}$, José Castaño-Pérez ${ }^{3}$, Juan Francisco Machado-Casas ${ }^{3}{ }^{\mathbb{D}}$, Ramón Coca-Zúñiga ${ }^{3}{ }^{\mathbb{D}}$, \\ José Miguel Pérez-Villares ${ }^{3}$ and Elena Planells ${ }^{1, *}$
}

1 Department of Physiology, Institute of Nutrition and Food Technology "Jose Mataix", School of Pharmacy, University of Granada, 18071 Granada, Spain; lourdesherrera@ugr.es (L.H.-Q.); jennifer_gamo@hotmail.com (Y.G.-M.); hectorvazquez@ugr.es (H.V.-L.)

2 Faculty of Education, Psychology and Sports Sciences, University of Huelva, 21007 Huelva, Spain

3 Intensive Care Unit, Virgen de las Nieves Hospital, Fuerzas Armadas Avenue, 18014 Granada, Spain; jcastaoperez@yahoo.com (J.C.-P.); jmachc2@hotmail.com (J.F.M.-C.);

ramon.coca.sspa@juntadeandalucia.es (R.C.-Z.); josem.perez.villares.sspa@juntadeandalucia.es (J.M.P.-V.)

* Correspondence: jorge.molina@ddi.uhu.es (J.M.-L.); elenamp@ugr.es (E.P.)

Citation: Herrera-Quintana, L.; Gamarra-Morales, Y.; Vázquez-Lorente, H.; Molina-López, J.; Castaño-Pérez,

J.; Machado-Casas, J.F.; Coca-Zúñiga, R.; Pérez-Villares, J.M.; Planells, E. Bad Prognosis in Critical Ill Patients with COVID-19 during Short-Term ICU Stay regarding Vitamin D Levels. Nutrients 2021, 13, 1988.

https://doi.org/10.3390/nu13061988

Academic Editors: Dimitrios

T. Karayiannis and Zafeiria Mastora

Received: 4 May 2021

Accepted: 5 June 2021

Published: 9 June 2021

Publisher's Note: MDPI stays neutral with regard to jurisdictional claims in published maps and institutional affiliations.

Copyright: (c) 2021 by the authors. Licensee MDPI, Basel, Switzerland. This article is an open access article distributed under the terms and conditions of the Creative Commons Attribution (CC BY) license (https:/ / creativecommons.org/licenses/by/ $4.0 /)$.
Abstract: Background and aims: Vitamin D inadequacy may be involved in the mechanisms of SARS-CoV-2 infection and in potential risk factors for disease propagation or control of coronavirus disease 2019 (COVID-19). This study assessed a short-term evolution of vitamin D status and its influence upon different clinical parameters in critically ill patients with COVID-19. Methods: A prospective analytical study in which 37 critically ill volunteers between 41 and 71 years of age with COVID-19 were evaluated at baseline and three days of intensive care unit (ICU) stay. 25-OH-D 3 and 25-OH- $\mathrm{D}_{2}$ were analyzed by liquid chromatography-tandem mass spectrometry and total 25-OH-D levels were calculated as the sum of both. Results: All patients presented low 25-OH-D levels at baseline, decreasing total 25-OH-D $(p=0.011)$ mainly through $25-\mathrm{OH}-\mathrm{D}_{2}(p=0.006)$ levels during ICU stay. $25-\mathrm{OH}-\mathrm{D}_{2}$ levels decreased a mean of $41.6 \% \pm 89.6 \%$ versus $7.0 \% \pm 23.4 \%$ for the $25-\mathrm{OH}-\mathrm{D}_{3}$ form during the ICU stay. Patients who did not need invasive mechanical ventilation presented higher levels of 25-OH-D 2 at baseline and follow-up. Lower 25-OH-D and 25-OH- $\mathrm{D}_{3}$ levels were associated with higher D-dimer at baseline $(p=0.003 ; p=0.001)$ and at follow up $(p=0.029)$, higher procalcitonin levels ( $p=0.002 ; p=0.018$ ) at follow up, and lower percentage lymphocyte counts $(p=0.044 ; p=0.040)$ during ICU stay. Conclusions: Deficient vitamin D status in critical patients was established at the admission and further worsened after three days of stay. Lower vitamin D levels were related to key altered clinical and biochemical parameters on patients with SARS-CoV-2 infection. Given the different response of the $25-\mathrm{OH}-\mathrm{D}_{3}$ and $25-\mathrm{OH}-\mathrm{D}_{2}$ forms, it would be useful to monitor them on the evolution of the critically ill patient.

Keywords: coronavirus disease 2019; SARS-CoV-2; Vitamin D; critical care; intensive care patient

\section{Introduction}

The global public health crisis caused by the SARS-CoV-2 virus has created the need for urgent actions in order to reduce the risk of infection, progression, and the severity of coronavirus disease 2019 (COVID-19) [1], which triggers an acute inflammatory process and uncontrolled oxidative stress [2]. This in turn results in severe acute respiratory distress syndrome (ARDS) characterized by a cytokine storm, mainly in critical cases [3], which may lead to multiple organ damage [4] and further complicate the patient's critical condition previously described during their ICU stay $[5,6]$.

There is currently great concern regarding the clinical management and intensive care of patients with critical stages of the disease and who are at a higher risk of death [7]. The implementation of prompt and appropriate nutritional assessment in COVID-19 must be 
considered, [8,9] because possible modulation of the status of key micronutrients appears to be a relevant factor influencing the development of this disease [10]. No information about nutritional monitoring in critical patients with COVID-19 is available to date [11], and this lack of data precludes the definition of firm micronutrient recommendations in this particular risk population [12].

Certain micronutrients are essential for adequate immunocompetence and antioxidant defense, which are related to inflammatory response, such as vitamin D [13]. 25-Hydroxyvitamin $\mathrm{D}(25-\mathrm{OH}-\mathrm{D})$ is the metabolite used to assess vitamin D status, due to its long half-life in plasma or serum (one month) [14], and is characterized by synergic action of its two main forms: 25-hydroxyvitamin $\mathrm{D}_{2}\left(25-\mathrm{OH}-\mathrm{D}_{2}\right)$, which is obtained from plant sources, and 25-hydroxyvitamin $\mathrm{D}_{3}\left(25-\mathrm{OH}-\mathrm{D}_{3}\right)$, which comes from animal products and endogenous synthesis in skin through exposure to sunlight [15], both of them can be supplemented with commercial products [16]. Recently, vitamin D has generated particular interest because of its role in reducing the risk of pneumonia and viral upper respiratory tract infections at a physical barrier and cellular natural and adaptive immunity level [17,18]. The underlying mechanisms can be grouped into two main actions: anti-inflammatory and anti-infective [19]. Vitamin D is associated with a decrease in proinflammatory cytokines, reducing the cytokine storm induced by the innate immune system, which is exacerbated in COVID-19 [17,20]. Moreover, it must be noted that serum 25-OH-D is considered as a negative acute phase reactant [21] and low vitamin D status in critical ill patients may be related to a decrease of binding protein concentration [22]. On the other hand, vitamin D is able to reduce viral infection and replication rates by inducing transcription of proteins with antimicrobial functions, enhancing autophagic encapsulation of viral particles, favoring lung epithelial cell barrier integrity, and ultimately regulating both innate and adaptive immunity $[17-20,23,24]$.

Thus, vitamin $\mathrm{D}$ inadequacy has emerged as a factor that may be involved in the mechanisms of virus infection and in potential risk factors for disease propagation or control [24,25]. In fact, low vitamin D status in patients with COVID-19 has been reported [26-28], being associated with a poorer prognosis, infection risk, or unregulated inflammation. Thus, due to the lack of evidence on the importance of monitoring vitamin D status in critical patients with COVID-19, the present study was designed to assess the short-term evolution of the status of vitamin $\mathrm{D}$ and its influence upon different clinical parameters in critically ill patients with COVID-19 in the province of Granada, Spain.

\section{Materials and Methods}

\subsection{Study Design and Subjects}

A prospective analytical study was carried out of patients monitored from the first day of admission to the intensive care unit (ICU) (baseline) until day three of stay (follow-up). Of a total of 43 initially recruited patients, 37 participants from the province of Granada (Spain), aged 41-74 years, were included in the period from 1 March to 1 June 2020, after been informed about the study protocol. Six patients died during the study and were excluded. All eligible participants enrolled in the study were critical patients aged 18 years or older and hospitalized for more than $48 \mathrm{~h}$, who agreed to participate in the study or for whom approval of participation was obtained from the family. All patients had a diagnosis of critical active SARS-CoV-2 infection according to the Chinese Clinical Guideline for the classification of COVID-19 [29] (analyzed by real-time reverse transcriptase-PCR (RT-PCR)) testing of nasal and pharyngeal swab samples) and had an ICU stay of at least three days and did not receive vitamin D support. The present study was conducted in accordance with the principles of the Declaration of Helsinki, following the International Conference on Harmonization/Good Clinical Practice standards, and was approved by the Ethics Committee of the University of Granada (Ref. 149/CEIH/2016). 


\subsection{Data Collection}

Data including age, sex, body mass index (BMI), smoking habits, comorbidities, respiratory and clinical parameters, ICU length of stay, length of hospitalization, and 28-day mortality were retrieved from the hospital electronic database system and recorded for each study participant at ICU admission (baseline) and after three days (follow-up). The Acute Physiology and Chronic Health Evaluation II (APACHE-II) score and Sequential Organ Failure Assessment (SOFA) score were obtained by intensivists at baseline and follow-up.

Patient clinical outcomes were recorded both at admission and during the ICU stay: heart rate (beats per minute); respiratory rate (breaths per minute); mean blood pressure $(\mathrm{mmHg})$; positive end-expiratory pressure (PEEP); fraction of inspired oxygen $\left(\mathrm{FiO}_{2}\right)$; partial oxygen arterial pressure/fraction of inspired oxygen $\left(\mathrm{PaO}_{2} / \mathrm{FiO}_{2}\right)$; ARDS; invasive mechanical ventilation (IMV).

\subsection{Blood Sampling and Biochemical Parameters}

Two measurements were performed (baseline and follow-up). Blood sampling was carried out in the morning under fasting conditions, followed by centrifugation $\left(4^{\circ} \mathrm{C}\right.$ for $15 \mathrm{~min}$ at $3500 \mathrm{rpm}$ ) to separate the plasma. The samples were frozen at $-80{ }^{\circ} \mathrm{C}$ until analysis of the different parameters. All samples were measured in one run, in the same assay batch, and blinded quality control samples were included in the same assay batches to determine laboratory error in the measurements.

The recorded biochemical parameters were total proteins, albumin, prealbumin, ferritin, transferrin, glucose, total cholesterol, glutamic oxaloacetic transaminase or aspartate transaminase (GOT or AST), glutamic pyruvic transaminase or alanine transaminase (GPT or ALT), lactate dehydrogenase (LDH), C-reactive protein (CRP), procalcitonin (PCT), hemoglobin, leukocytes, neutrophils, lymphocytes, platelets, D-dimer, fibrinogen, calcium $(\mathrm{Ca})$, phosphorous $(\mathrm{P})$, and magnesium $(\mathrm{Mg})$, using routine hospital analytical assays (ECLIA, Elecsys 2010 and Modular Analytics E170, Roche Diagnostics, Mannheim, Germany).

\subsection{Analytical Determination of Vitamin D}

Vitamin D was measured in plasma samples by liquid chromatography-tandem mass spectrometry (LC-MS/MS). Plasma sample treatment involved protein precipitation adding $500 \mu \mathrm{L}$ of acetonitrile in an Eppendorf flask with $200 \mu \mathrm{L}$ of plasma and $20 \mu \mathrm{L}$ of 25-hydroxyvitamin $\mathrm{D}_{3}$ and 25-hydroxyvitamin $\mathrm{D}_{2}$ deuterated solutions as Internal Standard (IS) (Sigma Aldrich, St. Louis, MO, USA) $(0.5 \mu \mathrm{g} / \mathrm{mL})$. The samples were slightly shaken for $1 \mathrm{~min}$ on a plate shaker and centrifuged at 10,000 rpm for $15 \mathrm{~min}$ at $4{ }^{\circ} \mathrm{C}$. The supernatant was collected in another Eppendorf flask and dried with $\mathrm{N}_{2}$. The dry residue was vortexed for $30 \mathrm{~s}$ after the addition of $200 \mu \mathrm{L}$ of ethyl acetate and $100 \mu \mathrm{L}$ of deionized water and centrifuged at $3000 \mathrm{rpm}$ for $5 \mathrm{~min}$. The supernatant was again collected in another Eppendorf flask, and the previous steps were repeated with the remaining liquid phase, subsequently pooling the second supernatant with the first. The total supernatant was dried with $\mathrm{N}_{2}$.

For samples derivatization, we prepared a solution of 4-phenyl-3H-1,2,4-triazole3,5(4H)-dione (PTAD) (Sigma Aldrich, St. Louis, MO, USA) in acetonitrile $(0.5 \mathrm{mg} / \mathrm{mL})$, using $50 \mu \mathrm{L}$ of this solution in standards and in each sample, with vortexing. All samples were placed on the plate shaker for $1 \mathrm{~h}$ at room temperature and covered with aluminum foil. Lastly, the samples were transferred to vials, diluted with $50 \mu \mathrm{L}$ of deionized water and stored in freezer at $-20{ }^{\circ} \mathrm{C}$ covered with aluminum foil until injection into the chromatograph. For the calibration line, increasing concentrations of 1, 2, 5, 10, 25, 50, and $100 \mathrm{ppb}$ of the standards $25-\mathrm{OH}-\mathrm{D}_{3}$ and $25-\mathrm{OH}-\mathrm{D}_{2}$ (Sigma Aldrich, St. Louis, MO, USA) with $20 \mu \mathrm{L}$ of IS were used and dried with $\mathrm{N}_{2}$ and derivatized at the same time as the samples. For sample measurements, use was made of a Waters Acquity UHPLC I-Class System chromatograph (Waters, London, UK), with the Acquity UHPLC BEH C18 column 2.1, $50 \mathrm{~mm}, 1.7 \mathrm{~m}$ at room temperature. The mobile phase of channel A was water 
with $50 \mathrm{mM}$ of ammonium formate, while that of channel B was methanol. The injection volume of the sample was $10 \mu \mathrm{L}$ and the flow rate was $0.4 \mathrm{~mL} / \mathrm{min}$. The detector was a Waters XEVO-TQ-XS Triple Quadrupole Low Resolution Spectrometer. Total 25-OH-D was calculated as the sum of the $25-\mathrm{OH}-\mathrm{D}_{3}$ and $25-\mathrm{OH}-\mathrm{D}_{2}$ forms. According to the Endocrine Society Practice Guidelines on Vitamin D, the threshold for biochemical 25-OH-D sufficiency values was considered to be $>30 \mathrm{ng} / \mathrm{mL}$, with deficiency being defined as 20-29 $\mathrm{ng} / \mathrm{mL}$ and insufficiency as $<20 \mathrm{ng} / \mathrm{mL}$ [28].

\subsection{Statistical Analysis}

Qualitative variables were presented as frequencies and percentages. Quantitative variables with normal distribution were expressed as the arithmetic mean and standard deviation (SD), and variables with non-normal distribution were expressed as the median and the interquartile range. Normal data distribution for continuous variables was tested using the Shapiro-Wilk test. The Wilcoxon signed-rank test for nonparametric samples was used for the comparative analyses at baseline and follow-up. The unpaired Student $t$-test for parametric samples was used for the comparative analysis based on clinical outcomes. The effect size (ES) was estimated and interpreted as follows: small $=0.01$, moderate $=0.06$, and large $=0.14$ [30]. Correlation analyses and partial correlation coefficients were performed using the Spearman test. Statistical significance was considered for $p<0.05$. The SPSS version 22.0 statistical package (IBM SPSS, Armonk, NY, USA) was used throughout.

\section{Results}

The demographic and clinical characteristics of the 37 patients enrolled in the study are shown in Table 1 . The median age of the study population was 60 years, and the gender distribution of the sample was 26 males and 11 females. With regard to the anthropometric parameters, over a third of the patients were overweight, and more than half of them were obese. Most of the patients had one or more underlying diseases. With regard to the severity parameters, the mean APACHE-II and SOFA scores were 12.3 and 6.54, respectively, upon admission. A total of 26 of 37 patients (70.2\%) had at least 1 infection, and 5 of them had 3 or more infections during their admission in ICU. The most frequent infection was bacteremia in 25 out of 48 total infections (52\%), followed by respiratory infections 15 out of 48 total infections (31\%), and finally urinary tract infections associated with urethral catheterization in 7 out of 48 total infections (14.5\%). The most frequent germs causing these infections were Gram-positive (39\%), followed by Gram-negative bacteria (33\%) and fungi (20\%). The mean length of hospitalization was 39.5 days. More than two-thirds of the patients presented ARDS on admission, requiring invasive mechanical ventilation with a mean duration of over 20 days. The mortality rate after 28 days of ICU stay was over two-thirds of the total study population.

The clinical and biochemical parameters of the study population at baseline and follow-up are shown in Table 2. Respiratory parameters were altered with significant changes in $\mathrm{FiO}_{2}$ and PEEP after three days. Total proteins $(p=0.012)$, albumin $(p=0.035)$, prealbumin $(p=0.017)$, LDH $(p=0.002)$, CRP $(p=0.001)$, hemoglobin $(p=0.001)$, and fibrinogen ( $p=0.001$ ) were outside the reference values and decreased significantly after three days of ICU stay. Parameters such as ferritin, transaminases, or D-dimer were also outside the reference values although no changes were observed in their evolution during the ICU stay. The results showed the 25-OH-D, 25-OH-D $\mathrm{D}_{3}$, and 25-OH- $\mathrm{D}_{2}$ levels to be lower at follow-up versus baseline-with statistical significance being reached for $25-\mathrm{OH}-\mathrm{D}$ $(p=0.011)$ and $25-\mathrm{OH}-\mathrm{D}_{2}(p=0.006)$.

Figure 1 shows the distribution of patient vitamin D status upon ICU admission and after three days of stay. In no case were the $25-\mathrm{OH}-\mathrm{D}$ levels $>25 \mathrm{ng} / \mathrm{mL}$. Only $16.7 \%(6 / 37)$ of the patients had 25-OH-D > $20 \mathrm{ng} / \mathrm{mL}$ at baseline, versus 3.2\% (1/37) at follow-up. Furthermore, 22.2\% (8/37) presented 25-OH-D $<10 \mathrm{ng} / \mathrm{mL}$-this percentage reaching $25.8 \%(10 / 37)$ after three days of stay. 
Table 1. Demographic and clinical characteristics of the patients.

\begin{tabular}{|c|c|c|c|}
\hline Baseline Characteristics $(N=37)$ & Mean \pm SD & Min-Max & $95 \% \mathrm{CI}$ \\
\hline Age (years) & $60.0 \pm 10.2$ & $41.0-74.0$ & $56.6-63.4$ \\
\hline $\operatorname{Sex}(M / F, \%)$ & $26 / 11(70.3 / 29.7)$ & - & - \\
\hline BMI $\left(\mathrm{kg} / \mathrm{m}^{2}\right)$ & $30.77 \pm 4.17$ & $22.8-42.2$ & $29.4-32.2$ \\
\hline $\mathrm{BMI}<25 \mathrm{~kg} / \mathrm{m}^{2}(n / N, \%)$ & $3 / 37(8.10)$ & - & - \\
\hline BMI $25-30 \mathrm{~kg} / \mathrm{m}^{2}(n / N, \%)$ & $14 / 37(37.8)$ & - & - \\
\hline $\mathrm{BMI}>30 \mathrm{~kg} / \mathrm{m}^{2}(n / N, \%)$ & $20 / 37(54.1)$ & - & - \\
\hline \multicolumn{4}{|l|}{ Smoking habit $(n / N, \%)$} \\
\hline Smokers & $3 / 37(8.10)$ & - & - \\
\hline Ex-smokers & $12 / 37(32.4)$ & - & - \\
\hline Never smokers & $22 / 37(59.5)$ & - & - \\
\hline Patients with comorbidity $(n / N, \%)$ & $26 / 37(70.3)$ & - & - \\
\hline Diabetes & $13 / 37(35.1)$ & - & - \\
\hline Hypertension & $20 / 37(54.1)$ & - & - \\
\hline Dyslipidemia & $11 / 37(29.7)$ & - & - \\
\hline Chronic kidney disease & $2 / 37(5.40)$ & - & - \\
\hline COPD & $10 / 37(27.0)$ & - & - \\
\hline Cardiovascular disease & $6 / 37(16.2)$ & - & - \\
\hline APACHE-II score & $12.3 \pm 3.77$ & $6.00-21.0$ & $11.1-13.6$ \\
\hline SOFA score & $6.54 \pm 2.60$ & $2.00-13.0$ & $5.67-7.41$ \\
\hline Bacterial and fungal infection $(n / N, \%)$ & $26 / 37(70.3)$ & - & - \\
\hline Sepsis $(n / N, \%)$ & $7 / 36(19.4)$ & - & - \\
\hline $\mathrm{PaO}_{2} / \mathrm{FiO}_{2}$ & $212.9 \pm 103.8$ & $15.0-550.0$ & $169.2-248.6$ \\
\hline $\operatorname{ARDS}\left(\mathrm{PaO}_{2} / \mathrm{FiO}_{2}<300\right)(n / N, \%)$ & $26 / 37(70.0)$ & - & - \\
\hline Mild $\left(300<\mathrm{PaO}_{2} / \mathrm{FiO}_{2} \leq 200\right)(n / N, \%)$ & $12 / 37(32.4)$ & - & - \\
\hline Moderate $\left(200<\mathrm{PaO}_{2} / \mathrm{FiO}_{2} \leq 100\right)(n / N, \%)$ & $10 / 37(27.0)$ & - & - \\
\hline Severe $\left(\mathrm{PaO}_{2} / \mathrm{FiO}_{2}<100\right)(n / N, \%)$ & $4 / 37(10.8)$ & - & - \\
\hline $\operatorname{IMV}(n / N, \%)$ & $30 / 37(81.1)$ & - & - \\
\hline Duration of IMV (days) & $21.7 \pm 14.6$ & $1.00-73.0$ & $16.0-27.4$ \\
\hline ICU length of stay (days) & $25.4 \pm 22.6$ & $6.00-104.0$ & $17.8-32.9$ \\
\hline Length of hospitalization (days) & $39.5 \pm 27.0$ & $9.00-131.0$ & $30.5-48.5$ \\
\hline Patient 28-day mortality $(n / N, \%)$ & $26 / 37(70.3)$ & - & - \\
\hline
\end{tabular}

$N=37$. Data expressed as mean \pm standard deviation. Abbreviations: $\mathrm{SD}=$ standard deviation; Min-Max = minimum-maximum; $\mathrm{CI}=$ confidence interval; $\mathrm{M} / \mathrm{F}=$ male/female; $\mathrm{BMI}=$ body mass index; $\mathrm{COPD}=$ chronic obstructive pulmonary disease; APACHE$\mathrm{II}=$ Acute Physiology and Chronic Health Evaluation II; SOFA = Sequential Organ Failure Assessment; $\mathrm{PaO}_{2} / \mathrm{FiO}_{2}=$ partial oxygen arterial pressure/fraction of inspired oxygen; ARDS = acute respiratory distress syndrome; IMV = invasive mechanical ventilation; ICU = intensive care unit.

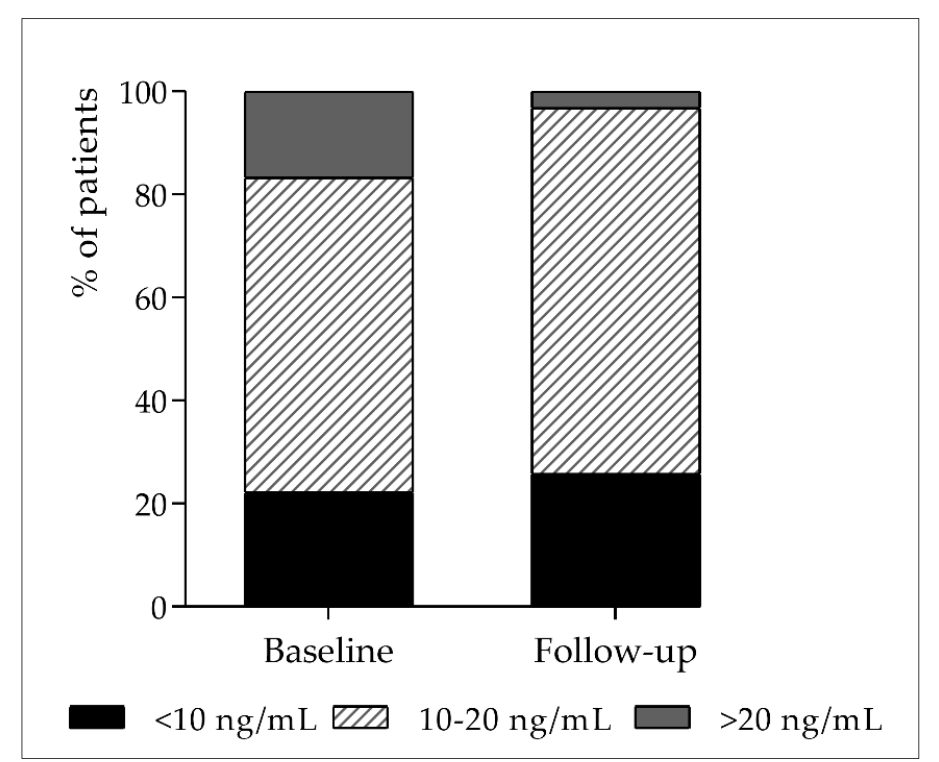

Figure 1. Vitamin D status in the study population at ICU admission (baseline) and after three days (follow-up). 
Table 2. Clinical and biochemical parameters of the critical patients with COVID-19 at baseline and follow-up.

\begin{tabular}{|c|c|c|c|c|c|c|}
\hline & Reference & $\begin{array}{c}\text { Baseline } \\
\text { Median (IQR) } \\
\quad N=37\end{array}$ & $\begin{array}{c}\text { Follow-Up } \\
\text { Median (IQR) } \\
\quad N=37\end{array}$ & $\mathbf{Z}$ & $\begin{array}{c}p \text {-Value } \\
\text { Initial-Final }\end{array}$ & ES \\
\hline \multicolumn{7}{|l|}{ Clinical } \\
\hline Heart rate (bpm) & $60-100$ & $80.0(28.7)$ & $64.0(38.0)$ & -1.69 & 0.091 & 0.411 \\
\hline Respiratory rate (brpm) & $15-20$ & $30.0(3.50)$ & $22.0(4.50)$ & -1.63 & 0.102 & 0.582 \\
\hline Mean blood pressure $(\mathrm{mmHg})$ & 70-105 & $93.5(18.0)$ & $91.5(25.7)$ & -0.31 & 0.753 & 0.095 \\
\hline $\operatorname{PEEP}\left(\mathrm{cm} \mathrm{H}_{2} \mathrm{O}\right)$ & $2-5$ & $14.0(3.50)$ & $12.0(2.00)$ & -2.76 & 0.006 & 0.779 \\
\hline $\mathrm{FiO}_{2}$ & $>68 \%$ & $0.70(0.25)$ & $0.60(0.15)$ & -3.81 & 0.001 & 0.825 \\
\hline $\mathrm{PaO}_{2} / \mathrm{FiO}_{2}$ & $200-300$ & $200.0(101.5)$ & $222.0(119.0)$ & -0.05 & 0.964 & 0.010 \\
\hline \multicolumn{7}{|l|}{ Biochemical } \\
\hline Total Proteins (g/dL) & $6.60-8.30$ & $6.40(0.90)$ & $6.10(1.13)$ & -2.51 & 0.012 & 0.513 \\
\hline Albumin (g/dL) & $3.50-5.20$ & $3.20(0.65)$ & $3.00(0.60)$ & -2.11 & 0.035 & 0.444 \\
\hline Prealbumin (mg/dL) & $16.0-42.0$ & $9.00(16.2)$ & $25.0(23.0)$ & -2.39 & 0.017 & 0.782 \\
\hline Ferritin $(\mathrm{ng} / \mathrm{mL})$ & $20.0-275.0$ & $1139.3(1772.9)$ & $1490.1(1815.7)$ & -0.52 & 0.603 & 0.117 \\
\hline Transferrin (mg/dL) & $200.0-360.0$ & $132.0(31.7)$ & $136.0(68.0)$ & -0.82 & 0.410 & 0.269 \\
\hline Glucose (mg/dL) & $75.0-115.0$ & $154.0(81.0)$ & $184.5(113.5)$ & -1.62 & 0.106 & 0.328 \\
\hline Total Cholesterol (mg/dL) & 140.0-200.0 & $138.5(51.5)$ & $159.0(103.0)$ & -2.02 & 0.044 & 0.574 \\
\hline GOT or AST $(\mathrm{U} / \mathrm{L})$ & $5.00-40.0$ & $37.0(32.5)$ & $31.0(32.0)$ & -1.76 & 0.078 & 0.351 \\
\hline GPT or ALT (U/L) & $0.00-55.0$ & $35.0(40.0)$ & $36.5(46.5)$ & -1.21 & 0.228 & 0.248 \\
\hline $\mathrm{LDH}(\mathrm{U} / \mathrm{L})$ & $0.00-248.0$ & $490.5(183.0)$ & $429.0(138.0)$ & -3.05 & 0.002 & 0.590 \\
\hline CRP (mg/L) & $0.00-5.00$ & $153.7(210.7)$ & $35.4(56.4)$ & -4.66 & 0.001 & 0.991 \\
\hline PCT $(\mathrm{ng} / \mathrm{dL})$ & $0.02-0.50$ & $0.22(0.44)$ & $0.11(0.46)$ & -1.59 & 0.112 & 0.360 \\
\hline Hemoglobin (g/dL) & $11.0-17.0$ & $13.3(2.80)$ & $12.6(3.93)$ & -4.06 & 0.001 & 0.789 \\
\hline Leukocytes $\left({ }^{*} 10^{3} / \mu \mathrm{L}\right)$ & $3.50-10.5$ & $9.67(6.94)$ & $9.45(7.44)$ & -1.25 & 0.212 & 0.240 \\
\hline Neutrophils (\%) & $42.0-77.0$ & $88.5(8.15)$ & $88.0(6.82)$ & -0.34 & 0.737 & 0.067 \\
\hline Lymphocytes (\%) & $20.0-44.0$ & $6.40(5.68)$ & $5.75(4.13)$ & -0.28 & 0.777 & 0.056 \\
\hline Platelets $\left({ }^{*} 10^{3} / \mu \mathrm{L}\right)$ & $120.0-450.0$ & $212.0(135.5)$ & $266.0(131.5)$ & -2.52 & 0.012 & 0.482 \\
\hline D-dimer (ng/dL) & $0.00-500.0$ & $1080.0(1647.5)$ & $1520.0(3050.0)$ & -1.14 & 0.254 & 0.231 \\
\hline Fibrinogen $(\mathrm{mg} / \mathrm{dL})$ & $200.0-350.0$ & $750.5(356.5)$ & $556.0(336.7)$ & -3.52 & 0.001 & 0.683 \\
\hline $\mathrm{Ca}(\mathrm{mg} / \mathrm{dL})$ & 8.80-10.6 & $8.40(0.48)$ & $8.10(0.98)$ & -0.81 & 0.421 & 0.190 \\
\hline $\mathrm{P}(\mathrm{mg} / \mathrm{dL})$ & $2.30-4.50$ & $3.55(1.93)$ & $3.15(1.43)$ & -0.02 & 0.984 & 0.005 \\
\hline $\mathrm{Mg}(\mathrm{mg} / \mathrm{dL})$ & $1.60-2.60$ & $2.23(0.37)$ & $2.20(0.50)$ & -0.80 & 0.421 & 0.253 \\
\hline 25-OH-D (ng/mL) & $20.0-100.0$ & $13.6(9.02)$ & $12.2(6.01)$ & -2.53 & 0.011 & 0.600 \\
\hline $25-\mathrm{OH}-\mathrm{D}_{3}(\mathrm{ng} / \mathrm{mL})$ & - & $8.45(6.38)$ & $7.92(5.85)$ & -1.35 & 0.176 & 0.520 \\
\hline $25-\mathrm{OH}-\mathrm{D}_{2}(\mathrm{ng} / \mathrm{mL})$ & - & $5.85(2.95)$ & $4.66(2.02)$ & -2.74 & 0.006 & 0.278 \\
\hline
\end{tabular}

$N=37$. Data expressed as median (interquartile range, IQR). Abbreviations: $\mathrm{SD}=$ standard deviation; $\mathrm{ES}=$ effect size; bpm $=$ beats per minute; brpm = breaths per minute; $\mathrm{PEEP}=$ positive end-expiratory pressure; $\mathrm{PaO}_{2} / \mathrm{FiO}_{2}=$ partial oxygen arterial pressure/fraction of inspired oxygen; GOT or AST = glutamic oxaloacetic transaminase or aspartate transaminase; GPT or ALT = glutamic pyruvic transaminase or alanine transaminase; $\mathrm{LDH}=$ lactate dehydrogenase; $\mathrm{CRP}=\mathrm{C}$-reactive protein; $\mathrm{PCT}=$ procalcitonin $; \mathrm{Ca}=$ calcium, $\mathrm{P}=$ phosphorous $\mathrm{Mg}=$ magnesium, ${ }^{*} 10^{3}=$ multiplied by 1000 . The sixth column reports statistical significance after the Wilcoxon signed-rank test; evolution is shown after 3 days. ES effect size calculations were also made to determine the effect of ICU stay (ES: small $\leq 0.01$, moderate $=0.06$, and large $\leq 0.14)$ [28]. Statistical significance $=p<0.05$.

Figure 2 corresponds to the comparative analysis of clinical parameters in relation to 25-OH-D, 25-OH- $\mathrm{D}_{3}$, and 25-OH-D 2 levels upon ICU admission and after three days of stay. Based on the sepsis (Figure 2A) and infectious processes (Figure 2B), there was a trend toward statistical significance in the follow-up observing lower levels of 25-OH-D and $25-\mathrm{OH}-\mathrm{D}_{3}$ for septic patients and lower levels of $25-\mathrm{OH}-\mathrm{D}_{2}$ for infected patients. Patients who did not need invasive mechanical ventilation presented higher levels of $25-\mathrm{OH}-\mathrm{D}_{2}$ at baseline and 25-OH-D and 25-OH- $\mathrm{D}_{2}$ at follow-up (Figure 2C).

Table 3 shows the Spearman bivariate correlations between the 25-OH-D, 25-OH$\mathrm{D}_{3}$, and 25-OH- $\mathrm{D}_{2}$ levels at baseline and follow-up and the clinical and biochemical parameters analyzed in our study. At baseline, the 25-OH-D levels were correlated to albumin $(p=0.021)$, hemoglobin $(p=0.028)$, D-dimer $(p=0.003)$, and fibrinogen $(p=0.020)$ with albumin also being correlated to $25-\mathrm{OH}-\mathrm{D}_{2}(p=0.037)$; and D-dimer $(p=0.001)$ and fibrinogen to $25-\mathrm{OH}-\mathrm{D}_{3}(p=0.029)$. Respiratory rate was negatively correlated to $25-\mathrm{OH}-\mathrm{D}_{2}(p=0.025)$. At follow-up, 25-OH-D and $25-\mathrm{OH}-\mathrm{D}_{3}$ were significantly correlated 
to PCT $(p=0.002 ; p=0.018)$ and lymphocytes $(p=0.044 ; p=0.040)$. In the case of Ddimer and $\mathrm{Ca}$, an inverse correlation to $25-\mathrm{OH}-\mathrm{D}_{3}$ was observed $(p=0.029$ and $p=0.006$, respectively). Finally, the $25-\mathrm{OH}-\mathrm{D}_{2}$ levels showed a significant correlation to both the fibrinogen $(p=0.003)$ and Ca levels $(p=0.030)$. We did not find correlation between mortality rate after 28 days of ICU stay and $25-\mathrm{OH}-\mathrm{D}_{3}, 25-\mathrm{OH}-\mathrm{D}_{2}$, and $25-\mathrm{OH}-\mathrm{D}$ levels.

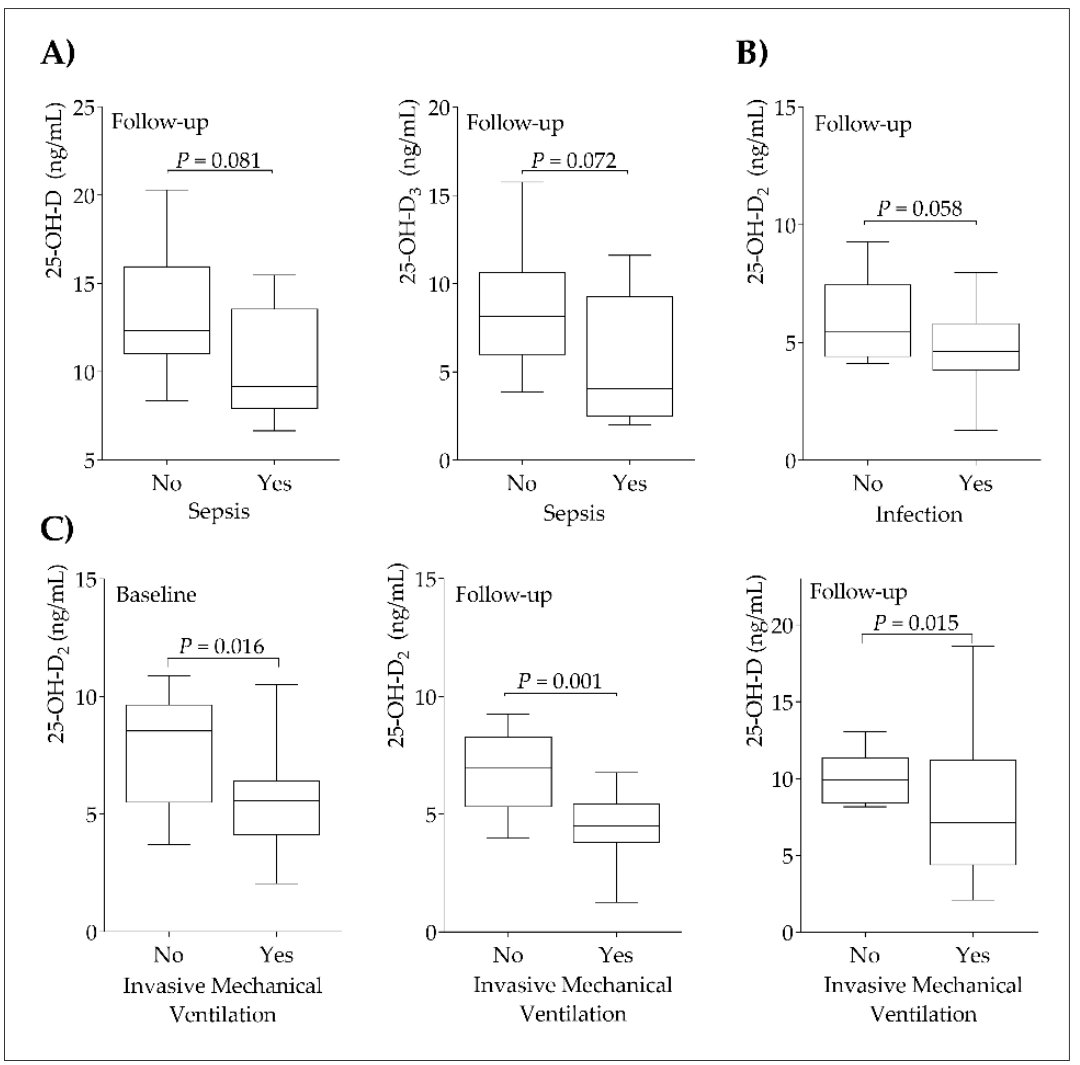

Figure 2. Comparative analysis of septic and non-septic patients with 25-OH-D and 25-OH- $\mathrm{D}_{3}$ levels at follow-up (A); infection with 25-OH-D 2 levels at follow-up (B); invasive mechanical ventilation with 25-OH-D 2 levels at baseline and 25-OH-D 2 and 25-OH-D levels at follow-up (C). Statistical significance $=p<0.05$.

Table 3. Matrix for correlation coefficients (rho) showing the simple linear relationship between clinical and biochemical parameters with 25-OH-D, 25-OH-D 2 , and 25-OH-D 3 levels.

\begin{tabular}{|c|c|c|c|c|c|c|}
\hline & \multicolumn{3}{|c|}{ Baseline } & \multicolumn{3}{|c|}{ Follow-Up } \\
\hline & $\begin{array}{l}\text { 25-OH-D } \\
\text { (ng/mL) }\end{array}$ & $\begin{array}{c}25-\mathrm{OH}-\mathrm{D}_{3} \\
\text { (ng/mL) }\end{array}$ & $\begin{array}{c}25-\mathrm{OH}-\mathrm{D}_{2} \\
\text { (ng/mL) }\end{array}$ & $\begin{array}{c}\text { 25-OH-D } \\
\text { (ng/mL) }\end{array}$ & $\begin{array}{c}25-\mathrm{OH}-\mathrm{D}_{3} \\
\text { (ng/mL) }\end{array}$ & $\begin{array}{c}\text { 25-OH-D } \\
\text { (ng/mL) }\end{array}$ \\
\hline Age (years) & -0.129 & -0.132 & -0.035 & -0.089 & -0.132 & 0.065 \\
\hline $\mathrm{BMI}\left(\mathrm{kg} / \mathrm{m}^{2}\right)$ & 0.111 & 0.165 & -0.026 & 0.091 & 0.261 & -0.231 \\
\hline APACHE-II & -0.103 & -0.066 & -0.040 & - & - & - \\
\hline SOFA & -0.154 & -0.053 & -0.167 & -0.133 & 0.008 & -0.290 \\
\hline Respiratory rate (brpm) & -0.176 & 0.053 & $-0.456^{\mathrm{a}}$ & -0.277 & 0.047 & -0.374 \\
\hline Albumin $(\mathrm{g} / \mathrm{dL})$ & $0.403^{\mathrm{a}}$ & 0.285 & $0.390^{\mathrm{a}}$ & 0.015 & -0.097 & 0.234 \\
\hline PCT (ng/dL) & -0.270 & -0.294 & -0.026 & $-0.587^{b}$ & $-0.458^{a}$ & -0.331 \\
\hline Hemoglobin (g/dL) & $0.387^{a}$ & 0.307 & 0.261 & 0.301 & 0.223 & 0.224 \\
\hline Lymphocytes (\%) & -0.046 & -0.059 & 0.084 & $0.364^{\mathrm{a}}$ & $0.371^{\mathrm{a}}$ & 0.034 \\
\hline D-dimer (ng/dL) & $-0.521^{b}$ & $-0.644^{b}$ & 0.148 & -0.264 & $-0.405^{a}$ & 0.302 \\
\hline Fibrinogen $(\mathrm{mg} / \mathrm{dL})$ & $0.350^{\mathrm{a}}$ & $0.370^{\mathrm{a}}$ & 0.128 & 0.116 & 0.335 & $-0.521^{b}$ \\
\hline $\mathrm{Ca}(\mathrm{mg} / \mathrm{dL})$ & 0.285 & 0.180 & 0.306 & -0.333 & $-0.527^{b}$ & $0.426^{\mathrm{a}}$ \\
\hline
\end{tabular}

Matrix correlations are presented as correlation coefficients (rho). Abbreviations: BMI = body mass index; APACHE-II = Acute Physiology and Chronic Health Evaluation II; SOFA = Sequential Organ Failure Assessment; $\mathrm{FiO}_{2}=$ fraction of inspired oxygen; $\mathrm{PCT}=$ procalcitonin; $\mathrm{Ca}=$ calcium. Statistical significance ${ }^{\mathrm{a}}=p<0.05{ }^{\mathrm{b}}=p<0.01$. 


\section{Discussion}

The main finding of the present study was the low 25-OH-D levels in the patients upon admission (baseline), followed by a significant decrease after three days of ICU stay. The entire population was below the sufficiency reference values for $25-\mathrm{OH}-\mathrm{D}$, and most of them presented insufficient 25-OH-D status. We also analyzed the 25-OH- $\mathrm{D}_{3}$ and $25-\mathrm{OH}-\mathrm{D}_{2}$ levels, both of which were seen to decrease after three days (though statistical significance was only reached in the case of $25-\mathrm{OH}-\mathrm{D}_{2}$ ), thus influencing upon 25-OH-D decreased levels and presenting a worsening during their stay at 3 days. Moreover, vitamin $\mathrm{D}$ was associated with clinical parameters such as the need for mechanical ventilation or respiratory frequency and with biochemical parameters also associated with the severity of the critically ill patient such as albumin, hemoglobin, D-dimer, fibrinogen, PCT, and lymphocytes.

Previous evidence points to poorer COVID-19 outcomes associated with factors such as the male gender, older age, BMI $>35 \mathrm{~kg} / \mathrm{m}^{2}$, and the presence of certain comorbidities [31]. The demographic and clinical characteristics of our patients (Table 1) are consistent with this evidence. In effect, the population was fundamentally elderly, two-thirds were males, and there was a high prevalence of comorbidities and obesity. It should be noted that metabolically ill patients with obesity may have a high risk of suffering inflammatory processes [32], which could contribute to a greater probability of poorer outcomes.

Many of the clinical and biochemical parameters in our patients were altered (Table 2). In the case of PEEP and $\mathrm{FiO}_{2}$, levels were above reference values and, they even decreased significantly in three days and remained altered in the most cases. It should be noted that ferritin, CRP, D-dimer, and fibrinogen were well above the reference values. Parameters related to inflammation (such as CRP) or coagulation (such as D-dimer) have been correlated to a poor prognosis and have been described as possible predictive biomarkers of COVID-19 [33].

Our results with reference to vitamin D status showed all patients to have insufficient levels $(<30 \mathrm{ng} / \mathrm{mL})$ both upon admission and during the study period-with the vitamin $\mathrm{D}$ status being seen to worsen in only three days. The great majority of patients presented vitamin D deficiency $(<20 \mathrm{ng} / \mathrm{mL}$ ), while extreme deficient values of $<10 \mathrm{ng} / \mathrm{mL}$ were recorded in a quarter of the study sample. It is known that, compared to the general population, the prevalence of hypovitaminosis $\mathrm{D}$ is greater in the critically ill and may constitute a risk factor for adverse outcomes [34]. Moreover, these levels could be influenced by seasonality. In an observational study carried out in critical ill patients from Austria, significant differences were noted in the prevalence of vitamin D deficiency and in the mean 25-OH-D values between the winter and summer months [35]. Our study covered the period from March to June; we, therefore, could not demonstrate the influence of seasonality in our patients.

On the other hand, there is concern about the high prevalence of hypovitaminosis $\mathrm{D}$ in the general population-being regarded as a global health issue with important consequences [36]. Moreover, SARS-CoV-2 positivity has been strongly and inversely correlated to circulating 25-OH-D levels-a relationship that persists across latitudes, races/ethnicities, both genders, and age ranges [37], thereby evidencing that the COVID19 fatality rates parallel the vitamin $\mathrm{D}$ deficiency rates [38]. These negative correlations between vitamin D deficiency and the number of COVID-19 cases and mortality have also been reported in another 20 European countries [39]. It could be expected that countries such as Spain have a better vitamin D status and therefore less severe consequences than other countries in northern Europe. However, our results reinforced the evidence of a possible widespread vitamin D deficiency in the Spanish population. Indeed, vitamin $\mathrm{D}$ deficiency in Italy and Spain (the countries presenting the highest age-specific case fatality ratio) [40] is more severe than elsewhere in Europe [41], particularly in the aging population [39].

On the other hand, Maghbooli et al. found 25-OH-D levels $>30 \mathrm{ng} / \mathrm{mL}$ to reduce the risk of adverse clinical outcomes in patients with COVID-19 [42]. None of our critical 
patients with COVID-19 presented 25-OH-D levels $>25 \mathrm{ng} / \mathrm{mL}$, which is consistent with the findings of Maghbooli. Low 25-OH-D levels have been reported by many authors in hospitalized patients with COVID-19 [43], with such deficiency being associated with a greater mortality risk [26]. In fact, Vassiliou et al. found that low 25-OH-D levels in patients with COVID-19 at ICU admission could predispose to an increased 28-day mortality risk [44]. In the present study, although we did not observe an association between 25-OH-D levels with 28-day mortality risk, we found an association with clinical outcomes, reporting that higher 25-OH-D and 25-OH- $\mathrm{D}_{2}$ levels were associated with those patients who did not require invasive mechanical ventilation. Moreover, lower 25-OH-D values, as a result of decreased $25-\mathrm{OH}-\mathrm{D}_{3}$ and $25-\mathrm{OH}-\mathrm{D}_{2}$ levels were observed with the presence of infection (bacterial/fungal) and sepsis (Figure 2). It should be noted that 25-OH- $\mathrm{D}_{2}$ levels were in agreement with previous studies in the Spanish population [45], being also similar to those found in other studies performed in Belgian and Chinese populations [46,47]. Likewise, observational studies have also shown that higher 25-OH-D levels would be associated with better clinical outcomes in respiratory diseases [48]. Nevertheless, reference values are needed to have more contrastable evidence on $25-\mathrm{OH}-\mathrm{D}_{2}$ levels.

In relation to infection, a high percentage of our patients $(70.3 \%)$ showed bacteriological or fungal infection, which would support the idea that the daily risk rate of infection in COVID-critically-ill patients is increased during ICU stay [49]. Recent studies [50], consistent with the high prevalence of hypovitaminosis D observed in our study, suggest a possible role of low vitamin D in the increased risk of SARS-CoV-2 infection and subsequent hospitalization. Likewise, 25-OH-D levels were inversely associated with coagulation and sepsis, in addition to major comorbidities. Both, 25-OH- $\mathrm{D}_{3}$ and $25-\mathrm{OH}-\mathrm{D}_{2}$ forms tended to respond differently in patients with bacteriological or fungal infection and in patients presenting sepsis. On the other hand, it was observed that $25-\mathrm{OH}-\mathrm{D}_{2}$ levels decreased a mean of $41.6 \% \pm 89.6 \%$ versus $7.0 \% \pm 23.4 \%$ for the $25-\mathrm{OH}-\mathrm{D}_{3}$ form during the ICU stay, which would suggest that the lack of vitamin D support during ICU stay could have allowed this more pronounced decrease in case of the $25-\mathrm{OH}-\mathrm{D}_{2}$ form, since it would depend on the intake through diet (before the admission) or its supplementation (during ICU stay). A greater decrease in $25-\mathrm{OH}-\mathrm{D}_{2}$ relative to $25-\mathrm{OH}-\mathrm{D}_{3}$ could be also related to the lower affinity of $25-\mathrm{OH}-\mathrm{D}_{2}$ for vitamin D-binding protein, leading to a shorter half-life and a higher rate of clearance from the circulation [51], and in some cases, it even caused a decline, thereby, precipitating in vitamin $\mathrm{D}$ deficiency [52]. This, together with the fact that there is literature that already reports a possible different role of $25-\mathrm{OH}-\mathrm{D}_{3}$ and $25-\mathrm{OH}-\mathrm{D}_{2}$ forms [51,53], although not in critical patients, could evidence the different correlations obtained with bacterial/fungal infection or sepsis and invasive mechanical ventilation previously described. Therefore, it would suggest that a lower vitamin D status at admission and worsening during three days of ICU stay may be a modifiable risk factor and an early predictive marker of adverse outcomes in hospitalized patients with COVID-19.

On associating the concentrations of both 25-OH-D and 25-OH-D 3 with other biochemical severity parameters, significantly lower vitamin D levels were correlated to higher D-dimer and PCT levels and a lower percentage of lymphocytes (Table 3). A recent metaanalysis has demonstrated that patients with severe COVID-19 tend to present increased leukocyte and neutrophil counts, neutrophil-lymphocyte ratio, PCT and CRP levels, and a decreased number of total lymphocytes, among parameters, compared to nonsevere individuals [54]. Furthermore, blood hypercoagulability is common among hospitalized patients with COVID-19. Elevated D-dimer levels are consistently reported in this scenario, and a gradual increase of this parameter in the course of the disease is particularly associated with patient worsening. Similarly, lower fibrinogen levels were found in nonsurvivor patients with COVID-19 [55]. In this line, the relationship between fibrinogen and 25-OH-D levels is often reported in the literature in noncritical patients [56,57]. In our study, 25-OH-D and 25-OH-D 3 levels were inversely correlated with D-dimer levels at baseline. Furthermore, 25-OH-D 3 levels have been correlated with fibrinogen levels at baseline. Our results may reflect a better vitamin $\mathrm{D}$ status (mainly due to vitamin $\mathrm{D}_{3}$ ) in 
patients with a more appropriate hematological profile. We observed a positive correlation at baseline between albumin (which was below the reference values) and the levels of both 25-OH-D and 25-OH-D 2 . Recently, low albumin levels have been regarded as more of a disease severity marker than as a marker of malnutrition, when such low levels are detected upon admission to hospital [58].

The present study has limitations and strengths. As limitations, the present study enrolled fewer patients than desired due to the difficulty in obtaining the sample and the patient's own clinical situation and severity both at admission and during the ICU stay. Therefore, the data should be treated with caution in order to generalize the findings of the study. Thus, on a comparative level, the effect size was shown for a better understanding. We had no reliable data on exposure to sunlight, dietary factors, or vitamin D supplementation - all of which affect vitamin D status. The overall negative results may be related to the heterogeneity of the subjects and their underlying disease conditions or severity, which may all influence the plasma 25-OH-D levels. Our findings cannot be generalized to other populations or ethnic groups, especially considering the wide range of COVID-19 prevalence. Replicating this study in a larger, prospective, and heterogeneous population and taking into account a control group, would allow for other stratified analyses based on demographic and biochemical characteristics, taking seasonality into account, and could further corroborate our findings. Additional research is therefore needed to validate our findings. As strengths, the present study used LC-MS/MS, which is the gold standard for assessing the levels of 25-OH-D [59], affording greater sensitivity, flexibility, and specificity than the enzymoimmunoassay techniques commonly used in clinical practice, which tend to overestimate the 25-OH-D values in cases of deficiency $[60,61]$.

Recent studies have reported encouraging results after vitamin D intervention $[62,63]$. However, further evidence is needed to confirm that improving vitamin D status is of benefit in reducing disease severity and mortality and the probability of developing a critical clinical condition. It is essential to ensure close patient monitoring before establishing intervention guidelines [64]. This study is one of the few that have been conducted in this context, assessing the short-term evolution of the 25-OH-D levels (through 25-OH- $\mathrm{D}_{2}$ and 25-OH-D $\mathrm{D}_{3}$ levels) and its impact in critical patients with COVID-19.

\section{Conclusions}

Our data reflect a high prevalence of hypovitaminosis D in all the critical patients at ICU admission, which increased after only three days of ICU stay. On the other hand, the associations observed between 25-OH-D levels, through $25-\mathrm{OH}-\mathrm{D}_{3}$ and $25-\mathrm{OH}-\mathrm{D}_{2}$ values and key clinical outcomes and biochemical altered parameters, suggests that it might be helpful to assess vitamin D status in patients with SARS-CoV-2 infection. Given the different response of the $25-\mathrm{OH}-\mathrm{D}_{3}$ and $25-\mathrm{OH}-\mathrm{D}_{2}$ forms, it would be useful to analyze them to elucidate the role of each form on the evolution of the critically ill patient. Further investigations are needed to define underlying mechanisms in vitamin D deficiency and useful strategies based on vitamin $\mathrm{D}$ interventions aimed at preserving vitamin $\mathrm{D}$ status and enhancing the clinical and biochemical profile of critical patients with COVID-19.

Author Contributions: Conceptualization, E.P., J.C.-P. and L.H.-Q.; methodology, J.M.-L. and J.M.P.V.; software, R.C.-Z., J.M.-L. and E.P.; validation, Y.G.-M. and J.F.M.-C.; formal analysis, L.H.-Q. and H.V.-L.; investigation, H.V.-L. and L.H.-Q.; resources, E.P. and H.V.-L.; data curation, J.M.-L.; writingoriginal draft preparation, L.H.-Q., Y.G.-M. and E.P.; writing—review and editing, H.V.-L. and J.M.-L.; visualization, L.H.-Q., Y.G.-M. and H.V.-L.; supervision, J.M.-L. and E.P.; project administration, E.P. and J.M.-L.; funding acquisition, E.P. All authors have read and agreed to the published version of the manuscript.

Funding: This research received external funding by FIS Projects from Carlos III Health Institute [REF. PI10/1993]. L.H.-Q. and H.V.-L. are under a FPU fellowship from the Spanish Ministry of Education. 
Institutional Review Board Statement: The study was approved by the Ethical Committee of the hospital, and informed consent was obtained from the patients or their family, who agreed to participate in the study.

Informed Consent Statement: Informed consent was obtained from all subjects involved in the study.

Data Availability Statement: The datasets generated and analyzed during the current study are not publicly available because the database is very extensive and includes data from other studies complementary to this but are available from the corresponding author on reasonable request.

Acknowledgments: Thanks are due to all the patients who participated in our study and the personnel from the Hospital Virgen de las Nieves, and FIBAO foundation (Fundación Pública Andaluza para la Investigación Biosanitaria de Andalucía Oriental Alejandro Otero) from Granada. We also acknowledge the expertise of the translator who provided English editing.

Conflicts of Interest: The authors declare no conflict of interest. The funders had no role in the design of the study; in the collection, analyses, or interpretation of data; in the writing of the manuscript; or in the decision to publish the results.

\section{References}

1. Ali, N. Role of Vitamin D in Preventing of COVID-19 Infection, Progression and Severity. J. Infect. Public Health 2020, 13, 1373-1380. [CrossRef] [PubMed]

2. De las Heras, N.; Martín Giménez, V.M.; Ferder, L.; Manucha, W.; Lahera, V. Implications of Oxidative Stress and Potential Role of Mitochondrial Dysfunction in COVID-19: Therapeutic Effects of Vitamin D. Antioxidants 2020, 9, 897. [CrossRef] [PubMed]

3. Han, H.; Ma, Q.; Li, C.; Liu, R.; Zhao, L.; Wang, W.; Zhang, P.; Liu, X.; Gao, G.; Liu, F.; et al. Profiling Serum Cytokines in COVID-19 Patients Reveals IL-6 and IL-10 Are Disease Severity Predictors. Emerg. Microbes Infect. 2020, 9, 1123-1130. [CrossRef] [PubMed]

4. Aygun, H. Vitamin D Can Prevent COVID-19 Infection-Induced Multiple Organ Damage. Naunyn. Schmiedebergs Arch. Pharmacol. 2020, 393, 1157-1160. [CrossRef] [PubMed]

5. Abilés, J.; Aguayo, E.; Moreno-Torres, R.; Llopis, J.; Aranda, P.; Argüelles, S.; Ayala, A. Oxidative Stress Is Increased in Critically Ill Patients According to Antioxidant Vitamins Intake, Independent of Severity: A Cohort Study. Crit. Care 2006, 10, R146. [CrossRef] [PubMed]

6. Gamarra, Y.; Santiago, F.C.; Molina-López, J.; Castaño, J.; Herrera-Quintana, L.; Domínguez, Á.; Planells, E. Pyroglutamic Acidosis by Glutathione Regeneration Blockage in Critical Patients with Septic Shock. Crit. Care 2019, 23, 162. [CrossRef] [PubMed]

7. Zhao, X.; Li, Y.; Ge, Y.; Shi, Y.; Lv, P.; Zhang, J.; Fu, G.; Zhou, Y.; Jiang, K.; Lin, N.; et al. Evaluation of Nutrition Risk and Its Association with Mortality Risk in Severely and Critically Ill COVID-19 Patients. J. Parenter. Enter. Nutr. 2020, 45, 32-42. [CrossRef] [PubMed]

8. Laviano, A.; Koverech, A.; Zanetti, M. Nutrition Support in the Time of SARS-CoV-2 (COVID-19). Nutrition 2020, 74, 110834. [CrossRef] [PubMed]

9. Barazzoni, R.; Bischoff, S.C.; Breda, J.; Wickramasinghe, K.; Krznaric, Z.; Nitzan, D.; Pirlich, M.; Singer, P. ESPEN Expert Statements and Practical Guidance for Nutritional Management of Individuals with SARS-CoV-2 Infection. Clin. Nutr. 2020, 39, 1631-1638. [CrossRef] [PubMed]

10. Zabetakis, I.; Lordan, R.; Norton, C.; Tsoupras, A. COVID-19: The Inflammation Link and the Role of Nutrition in Potential Mitigation. Nutrients 2020, 12, 1466. [CrossRef]

11. Caccialanza, R.; Laviano, A.; Lobascio, F.; Montagna, E.; Bruno, R.; Ludovisi, S.; Corsico, A.G.; Di Sabatino, A.; Belliato, M.; Calvi, M.; et al. Early Nutritional Supplementation in Non-Critically Ill Patients Hospitalized for the 2019 Novel Coronavirus Disease (COVID-19): Rationale and Feasibility of a Shared Pragmatic Protocol. Nutrition 2020, 74, 110835. [CrossRef] [PubMed]

12. Patel, J.J.; Martindale, R.G.; McClave, S.A. Relevant Nutrition Therapy in COVID-19 and the Constraints on Its Delivery by a Unique Disease Process. Nutr. Clin. Pract. 2020, 35, 792-799. [CrossRef] [PubMed]

13. Alexander, J.; Tinkov, A.; Strand, T.A.; Alehagen, U.; Skalny, A.; Aaseth, J. Early Nutritional Interventions with Zinc, Selenium and Vitamin D for Raising Anti-Viral Resistance Against Progressive COVID-19. Nutrients 2020, 12, 2358. [CrossRef] [PubMed]

14. Van den Ouweland, J.M.W. Analysis of Vitamin D Metabolites by Liquid Chromatography-Tandem Mass Spectrometry. TrAC Trends Anal. Chem. 2016, 84, 117-130. [CrossRef]

15. Higashi, T.; Shimada, K.; Toyo'oka, T. Advances in Determination of Vitamin D Related Compounds in Biological Samples Using Liquid Chromatography-Mass Spectrometry: A Review. J. Chromatogr. B 2010, 878, 1654-1661. [CrossRef]

16. Gottschlich, M.M.; Mayes, T.; Khoury, J.; Kagan, R.J. Clinical Trial of Vitamin $\mathrm{D}_{2}$ vs. $\mathrm{D}_{3}$ Supplementation in Critically Ill Pediatric Burn Patients. J. Parenter. Enter. Nutr. 2017, 41, 412-421. [CrossRef] [PubMed]

17. Grant, W.B.; Lahore, H.; McDonnell, S.L.; Baggerly, C.A.; French, C.B.; Aliano, J.L.; Bhattoa, H.P. Evidence That Vitamin D Supplementation Could Reduce Risk of Influenza and COVID-19 Infections and Deaths. Nutrients 2020, 12, 988. [CrossRef] [PubMed] 
18. Martín Giménez, V.M.; Inserra, F.; Tajer, C.D.; Mariani, J.; Ferder, L.; Reiter, R.J.; Manucha, W. Lungs as Target of COVID-19 Infection: Protective Common Molecular Mechanisms of Vitamin D and Melatonin as a New Potential Synergistic Treatment. Life Sci. 2020, 254, 117808. [CrossRef] [PubMed]

19. Mansur, J.L.; Tajer, C.; Mariani, J.; Inserra, F.; Ferder, L.; Manucha, W. Vitamin D high doses supplementation could represent a promising alternative to prevent or treat COVID-19 infection. Clín. Investig. Arterioscler. 2020, 32, 267-277. [CrossRef] [PubMed]

20. Weir, E.K.; Thenappan, T.; Bhargava, M.; Chen, Y. Does Vitamin D Deficiency Increase the Severity of COVID-19? Clin. Med. 2020, 20, e107-e108. [CrossRef] [PubMed]

21. Waldron, J.L.; Ashby, H.L.; Cornes, M.P.; Bechervaise, J.; Razavi, C.; Thomas, O.L.; Chugh, S.; Deshpande, S.; Ford, C.; Gama, R. Vitamin D: A Negative Acute Phase Reactant. J. Clin. Pathol. 2013, 66, 620-622. [CrossRef] [PubMed]

22. Heijboer, A.C.; Blankenstein, M.A.; Kema, I.P.; Buijs, M.M. Accuracy of 6 Routine 25-Hydroxyvitamin D Assays: Influence of Vitamin D Binding Protein Concentration. Clin. Chem. 2012, 58, 543-548. [CrossRef] [PubMed]

23. Teymoori-Rad, M.; Marashi, S.M. Vitamin D and Covid-19: From Potential Therapeutic Effects to Unanswered Questions. Rev. Med. Virol. 2020, 31, e2159. [CrossRef] [PubMed]

24. Bilezikian, J.P.; Bikle, D.; Hewison, M.; Lazaretti-Castro, M.; Formenti, A.M.; Gupta, A.; Madhavan, M.V.; Nair, N.; Babalyan, V.; Hutchings, N.; et al. Mechanisms in endocrinology: Vitamin D and COVID-19. Eur. J. Endocrinol. 2020, 183, R133-R147. [CrossRef] [PubMed]

25. Xu, Y.; Baylink, D.J.; Chen, C.-S.; Reeves, M.E.; Xiao, J.; Lacy, C.; Lau, E.; Cao, H. The Importance of Vitamin d Metabolism as a Potential Prophylactic, Immunoregulatory and Neuroprotective Treatment for COVID-19. J. Transl. Med. 2020, 18, 322. [CrossRef] [PubMed]

26. Carpagnano, G.E.; Di Lecce, V.; Quaranta, V.N.; Zito, A.; Buonamico, E.; Capozza, E.; Palumbo, A.; Di Gioia, G.; Valerio, V.N.; Resta, O. Vitamin D Deficiency as a Predictor of Poor Prognosis in Patients with Acute Respiratory Failure Due to COVID-19. J. Endocrinol. Investig. 2020, 44, 765-771. [CrossRef] [PubMed]

27. Meltzer, D.O.; Best, T.J.; Zhang, H.; Vokes, T.; Arora, V.; Solway, J. Association of Vitamin D Status and Other Clinical Characteristics With COVID-19 Test Results. JAMA Netw. Open 2020, 3, e2019722. [CrossRef] [PubMed]

28. Holick, M.F.; Binkley, N.C.; Bischoff-Ferrari, H.A.; Gordon, C.M.; Hanley, D.A.; Heaney, R.P.; Murad, M.H.; Weaver, C.M. Evaluation, Treatment, and Prevention of Vitamin D Deficiency: An Endocrine Society Clinical Practice Guideline. J. Clin. Endocrinol. Metab. 2011, 96, 1911-1930. [CrossRef] [PubMed]

29. Zhao, J.Y.; Yan, J.Y.; Qu, J.M. Interpretations of “Diagnosis and Treatment Protocol for Novel Coronavirus Pneumonia (Trial Version 7)". Chin. Med. J. 2020, 133, 1347-1349. [CrossRef]

30. Cohen, J. A Power Primer. Psychol. Bull. 1992, 112, 155-159. [CrossRef] [PubMed]

31. Rapp, J.; Lieberman-Cribbin, W.; Tuminello, S.; Taioli, E. Male Sex, Severe Obesity, Older Age, and Chronic Kidney Disease Are Associated With COVID-19 Severity and Mortality in New York City. Chest 2020, 159, 112-115. [CrossRef] [PubMed]

32. Chiappetta, S.; Sharma, A.M.; Bottino, V.; Stier, C. COVID-19 and the Role of Chronic Inflammation in Patients with Obesity. Int J. Obes. 2020, 44, 1790-1792. [CrossRef] [PubMed]

33. Ponti, G.; Maccaferri, M.; Ruini, C.; Tomasi, A.; Ozben, T. Biomarkers associated with COVID-19 disease progression. Crit. Rev. Clin. Lab. Sci. 2020, 57, 389-399. [CrossRef] [PubMed]

34. Christopher, K.B. Vitamin D and Critical Illness Outcomes. Curr. Opin. Crit. Care 2016, 22, 332-338. [CrossRef] [PubMed]

35. Amrein, K.; Zajic, P.; Schnedl, C.; Waltensdorfer, A.; Fruhwald, S.; Holl, A.; Purkart, T.; Wünsch, G.; Valentin, T.; Grisold, A.; et al. Vitamin D Status and Its Association with Season, Hospital and Sepsis Mortality in Critical Illness. Crit. Care 2014, 18 , R47. [CrossRef] [PubMed]

36. Holick, M.F. The Vitamin D Deficiency Pandemic: Approaches for Diagnosis, Treatment and Prevention. Rev. Endocr. Metab. Disord. 2017, 18, 153-165. [CrossRef]

37. Kaufman, H.W.; Niles, J.K.; Kroll, M.H.; Bi, C.; Holick, M.F. SARS-CoV-2 Positivity Rates Associated with Circulating 25-Hydroxyvitamin D Levels. PLoS ONE 2020, 15, e0239252. [CrossRef] [PubMed]

38. Benskin, L.L. A Basic Review of the Preliminary Evidence That COVID-19 Risk and Severity Is Increased in Vitamin D Deficiency. Front. Public Health 2020, 8, 513. [CrossRef] [PubMed]

39. Ilie, P.C.; Stefanescu, S.; Smith, L. The Role of Vitamin D in the Prevention of Coronavirus Disease 2019 Infection and Mortality. Aging Clin. Exp. Res. 2020, 32, 1195-1198. [CrossRef] [PubMed]

40. Daneshkhah, A.; Agrawal, V.; Eshein, A.; Subramanian, H.; Roy, H.K.; Backman, V. Evidence for possible association of vitamin D status with cytokine storm and unregulated inflammation in COVID-19 patients. Aging Clin. Exp. Res. 2020, 32, $2141-2158$. [CrossRef] [PubMed]

41. Lips, P.; Cashman, K.D.; Lamberg-Allardt, C.; Bischoff-Ferrari, H.A.; Obermayer-Pietsch, B.; Bianchi, M.L.; Stepan, J.; Fuleihan, G.E.; Bouillon, R. Current vitamin D status in European and Middle East coun-tries and strategies to prevent vitamin D deficiency: A position statement of the European Calcified Tissue Society. Eur. J. Endocrinol. 2019, 180, P23-P54. [CrossRef] [PubMed]

42. Maghbooli, Z.; Sahraian, M.A.; Ebrahimi, M.; Pazoki, M.; Kafan, S.; Tabriz, H.M.; Hadadi, A.; Montazeri, M.; Nasiri, M.; Shirvani, A.; et al. Vitamin D Sufficiency, a Serum 25-Hydroxyvitamin D at Least $30 \mathrm{Ng} / \mathrm{ML}$ Reduced Risk for Adverse Clinical Outcomes in Patients with COVID-19 Infection. PLoS ONE 2020, 15, e0239799. [CrossRef] [PubMed] 
43. Cereda, E.; Bogliolo, L.; Klersy, C.; Lobascio, F.; Masi, S.; Crotti, S.; De Stefano, L.; Bruno, R.; Corsico, A.G.; Di Sabatino, A.; et al. Vitamin D 25OH Deficiency in COVID-19 Patients Admitted to a Tertiary Referral Hospital. Clin. Nutr. 2020, 40, $2469-2472$. [CrossRef] [PubMed]

44. Vassiliou, A.G.; Jahaj, E.; Pratikaki, M.; Orfanos, S.E.; Dimopoulou, I.; Kotanidou, A. Low 25-Hydroxyvitamin D Levels on Admission to the Intensive Care Unit May Predispose COVID-19 Pneumonia Patients to a Higher 28-Day Mortality Risk: A Pilot Study on a Greek ICU Cohort. Nutrients 2020, 12, 3773. [CrossRef]

45. Vázquez-Lorente, H.; Herrera-Quintana, L.; Molina-López, J.; Gamarra-Morales, Y.; López-González, B.; Miralles-Adell, C.; Planells, E. Response of Vitamin D after Magnesium Intervention in a Postmenopausal Population from the Province of Granada, Spain. Nutrients 2020, 12, 2283. [CrossRef] [PubMed]

46. Swanson, C.M.; Nielson, C.M.; Shrestha, S.; Lee, C.G.; Barrett-Connor, E.; Jans, I.; Cauley, J.A.; Boonen, S.; Bouillon, R.; Vanderschueren, D.; et al. Higher 25(OH)D2 Is Associated with Lower 25(OH)D3 and 1,25(OH)2D3. J. Clin. Endocrinol. Metab. 2014, 99, 2736-2744. [CrossRef] [PubMed]

47. Wang, L.; Liu, X.; Hou, J.; Wei, D.; Liu, P.; Fan, K.; Zhang, L.; Nie, L.; Li, X.; Huo, W.; et al. Serum Vitamin D Affected Type 2 Diabetes Though Altering Lipid Profile and Modified the Effects of Testosterone on Diabetes Status. Nutrients 2020, 13, 90. [CrossRef]

48. Cannell, J.J.; Vieth, R.; Umhau, J.C.; Holick, M.F.; Grant, W.B.; Madronich, S.; Garland, C.F.; Giovannucci, E. Epidemic Influenza and Vitamin D. Epidemiol. Infect. 2006, 134, 1129-1140. [CrossRef] [PubMed]

49. Buetti, N.; Ruckly, S.; de Montmollin, E.; Reignier, J.; Terzi, N.; Cohen, Y.; Shiami, S.; Dupuis, C.; Timsit, J.-F. COVID-19 Increased the Risk of ICU-Acquired Bloodstream Infections: A Case-Cohort Study from the Multicentric OUTCOMEREA Network. Intensive Care Med. 2021, 47, 180-187. [CrossRef]

50. Infante, M.; Buoso, A.; Pieri, M.; Lupisella, S.; Nuccetelli, M.; Bernardini, S.; Fabbri, A.; Iannetta, M.; Andreoni, M.; Colizzi, V.; et al . Low Vitamin D Status at Admission as a Risk Factor for Poor Survival in Hospitalized Patients with COVID-19: An Italian Retrospective Study. J. Am. Coll. Nutr. 2021, 1-16. [CrossRef] [PubMed]

51. Houghton, L.A.; Vieth, R. The Case against Ergocalciferol (Vitamin D2) as a Vitamin Supplement. Am. J. Clin. Nutr. 2006, 84, 694-697. [CrossRef] [PubMed]

52. Holick, M.F. The D-Sparaging of Vitamin D2: How Physiologically and Pharmacologically Relevant Is It for the Clinician? J. Clin. Endocrinol. Metab. 2020, 105, e1913-e1915. [CrossRef] [PubMed]

53. Bigman, G. Vitamin D Metabolites, D3 and D2, and Their Independent Associations with Depression Symptoms among Adults in the United States. Nutr. Neurosci. 2020, 1-9. [CrossRef]

54. Feng, X.; Li, S.; Sun, Q.; Zhu, J.; Chen, B.; Xiong, M.; Cao, G. Immune-Inflammatory Parameters in COVID-19 Cases: A Systematic Review and Meta-Analysis. Front. Med. 2020, 7, 301. [CrossRef] [PubMed]

55. Terpos, E.; Ntanasis-Stathopoulos, I.; Elalamy, I.; Kastritis, E.; Sergentanis, T.N.; Politou, M.; Psaltopoulou, T.; Gerotziafas, G.; Dimopoulos, M.A. Hematological Findings and Complications of COVID -19. Am. J. Hematol. 2020, 95, 834-847. [CrossRef] [PubMed]

56. Parikh, S.; Guo, D.; Pollock, N.K.; Petty, K.; Bhagatwala, J.; Gutin, B.; Houk, C.; Zhu, H.; Dong, Y. Circulating 25-Hydroxyvitamin D Concentrations Are Correlated with Cardiometabolic Risk Among American Black and White Adolescents Living in a Year-Round Sunny Climate. Diabetes Care 2012, 35, 1133-1138. [CrossRef] [PubMed]

57. Saghir Afifeh, A.M.; Verdoia, M.; Nardin, M.; Negro, F.; Viglione, F.; Rolla, R.; De Luca, G. Determinants of Vitamin D Activation in Patients with Acute Coronary Syndromes and Its Correlation with Inflammatory Markers. Nutr. Metab. Cardiovasc. Dis. 2020, 31, 36-43. [CrossRef] [PubMed]

58. Berger, M.M.; Reintam-Blaser, A.; Calder, P.C.; Casaer, M.; Hiesmayr, M.J.; Mayer, K.; Montejo, J.C.; Pichard, C.; Preiser, J.-C.; van Zanten, A.R.H.; et al. Monitoring Nutrition in the ICU. Clin. Nutr. 2019, 38, 584-593. [CrossRef] [PubMed]

59. Vázquez-Lorente, H.; Herrera-Quintana, L.; Quintero-Osso, B.; Molina-López, J.; Planells, E. Current Trends in the Analytical Determination of Vitamin D. Nutr. Hosp. 2019, 36, 1418-1423. [PubMed]

60. Tahsin-Swafiri, S.; Blanco-Navarro, I.; Pérez-Sacristán, B.; Millán, I.; Granado-Lorencio, F. The Prevalence of Vitamin Deficiency in Clinical Practice Is Assay-Dependent. Clin. Nutr. 2012, 31, 1011-1014. [CrossRef]

61. Rousseau, A.-F.; Damas, P.; Janssens, M.; Kalin, S.; Ledoux, D.; Le Goff, C.; Gadisseur, R.; Delanaye, P.; Cavalier, E. Critical Care and Vitamin D Status Assessment: What about Immunoassays and Calculated Free 25OH-D? Clin. Chim. Acta 2014, $437,43-47$. [CrossRef] [PubMed]

62. Annweiler, C.; Hanotte, B.; Grandin de l'Eprevier, C.; Sabatier, J.-M.; Lafaie, L.; Célarier, T. Vitamin D and Survival in COVID-19 Patients: A Quasi-Experimental Study. J. Steroid Biochem. Mol. Biol. 2020, 204, 105771. [CrossRef] [PubMed]

63. Entrenas Castillo, M.; Entrenas Costa, L.M.; Vaquero Barrios, J.M.; Alcalá Díaz, J.F.; Miranda, J.L.; Bouillon, R.; Quesada Gómez, J.M. Effect of calcifediol treatment and best available therapy versus best available therapy on intensive care unit admission and mortality among patients hospitalized for COVID-19: A pilot randomized clinical study. J. Steroid Biochem. Mol. Biol. 2020, 203, 105751. [CrossRef] [PubMed]

64. Ebadi, M.; Montano-Loza, A.J. Perspective: Improving Vitamin D Status in the Management of COVID-19. Eur. J. Clin. Nutr. 2020, 74, 856-859. [CrossRef] [PubMed] 